\title{
In vitro testing of calcium phosphate (HA, TCP, and biphasic HA-TCP) whiskers
}

\author{
Sahil Jalota, Sarit B. Bhaduri, A. Cuneyt Tas \\ School of Materials Science and Engineering, Clemson University, Clemson, South Carolina 29634
}

Received 28 December 2004; revised 7 October 2005; accepted 24 March 2006

Published online 23 May 2006 in Wiley InterScience (www.interscience.wiley.com). DOI: 10.1002/jbm.a.30851

\begin{abstract}
Calcium phosphate [single-phase hydroxyapatite $\left(\mathrm{HA}, \mathrm{Ca}_{10}\left(\mathrm{PO}_{4}\right)_{6}(\mathrm{OH})_{2}\right)$, single-phase tricalcium phosphate $\left(\beta-\mathrm{TCP}, \mathrm{Ca}_{3}\left(\mathrm{PO}_{4}\right)_{2}\right)$, and biphasic HA-TCP] whiskers were formed by using a novel microwave-assisted molten salt mediated process. Aqueous solutions containing $\mathrm{NaNO}_{3}, \mathrm{HNO}_{3}, \mathrm{Ca}\left(\mathrm{NO}_{3}\right)_{2} \cdot 4 \mathrm{H}_{2} \mathrm{O}$, and $\mathrm{KH}_{2} \mathrm{PO}_{4}$ (with or without urea) were used as starting reagents. These solutions were irradiated in a household microwave oven for $5 \mathrm{~min}$. As-recovered precursors were then simply stirred in water at room temperature for $1 \mathrm{~h}$ to obtain the whiskers of the desired calcium phosphate $(\mathrm{CaP})$ bioceramics. These whiskers were evaluated, respectively, in vitro by (1) soaking those in synthetic body fluid (SBF) solutions at $37^{\circ} \mathrm{C}$ for one
\end{abstract}

week, and (2) performing cell attachment and total protein assay tests on the neat whiskers by using a mouse osteoblast cell line (7F2). $\beta$-TCP, HA, and HA-TCP biphasic whiskers were all found to possess apatite-inducing ability when soaked in SBF. SBF-soaked whiskers were found to have BET surface areas ranging from 45 to $112 \mathrm{~m}^{2} / \mathrm{g}$. Although the osteoblast viability and protein concentrations were found to be the highest on the neat HA whiskers, cells were attached and proliferated on all the whiskers. (C) 2006 Wiley Periodicals, Inc. J Biomed Mater Res 78A: 481-490, 2006

Key words: whisker; osteoblast; in vitro; calcium phosphate

\section{INTRODUCTION}

It is known that whiskers or fibers of many materials can be synthesized; however, the preparation of non-toxic and biocompatible whiskers still remains as an important task. Asbestos whiskers, for instance, which have been used for so many decades, are now known to be biohazardous and extremely carcinogenic. ${ }^{1}$ Toxicity and carcinogenic properties of $\mathrm{SiC}$ whiskers is well known. ${ }^{2-4}$ Therefore, it is important to explore other whiskers that are more biocompatible. Human body uses only the carbonated, alkali $\left(\mathrm{Na}^{+}\right.$ and $\left.\mathrm{K}^{+}\right)$and alkaline earth $\left(\mathrm{Mg}^{2+}\right)$ ion-doped, apatitic calcium phosphate as the sole inorganic, "ceramic" phase, when and where it needs to exploit the loadbearing ability of such strong materials. Therefore, whiskers of carbonated, apatitic calcium phosphates $(\mathrm{CaP})$ are non-toxic and perfectly compatible with the human body. ${ }^{5-14}$ Until now CaP whiskers were synthesized with the aim of using them as possible strengthening additives for the calcium phosphate (e.g., HA: $\left.\mathrm{Ca}_{10}\left(\mathrm{PO}_{4}\right)_{6}(\mathrm{OH})_{2}\right)$ bioceramics. Within this

Correspondence to: A. C. Tas; e-mail: actas@clemson.edu Contract grant sponsor: NSF; contract grant number: 04049119

(c) 2006 Wiley Periodicals, Inc. context, reinforcement by whiskers has been regarded as a means of raising the fracture toughness of singlephase HA from $<1$ to $2-12 \mathrm{MPa} \mathrm{m}{ }^{1 / 2} \cdot{ }^{15-17}$ We have recently reported ${ }^{18}$ a novel procedure that allowed us to synthesize short whiskers of single-phase HA, single-phase TCP, or biphasic HA-TCP.

Yoshimura and coworkers ${ }^{1,7,9,11}$ laid the foundation for the hydrothermal synthesis of hydroxyapatite whiskers and also for their use in reinforcing calcium phosphate bioceramics. ${ }^{19}$ These hydrothermal whisker synthesis procedures, which required aqueous solutions to be heated to $160-200^{\circ} \mathrm{C}$ in autoclaves, are not suitable (owing to the increased solubility and/or hydrolysis of $\beta$-TCP phase under such conditions) for the production of $\beta$-TCP or biphasic $\beta$-TCP-HA whiskers. ${ }^{20}$ Molten salt synthesis techniques, on the other hand, are suitable for the synthesis of monodisperse $\beta$-TCP or biphasic whiskers. ${ }^{10}$

To the best of our knowledge, none of the previously synthesized calcium phosphate whiskers was in vitro tested by using the osteoblast cell lines. Until now the osteoblast attachment and proliferation have been reported only on SiC whiskers, which were used to reinforce calcium phosphate self-setting cements, bioceramics, or polymers. ${ }^{21-24}$ The apatite-inducing ability of CaP whiskers, ${ }^{5-14,18}$ when soaked in synthetic body fluid (SBF) solutions, ${ }^{25-27}$ was also not studied or reported yet. 
TABLE I

Sample Preparation for HA, TCP, and Biphasic HA-TCP Whiskers ${ }^{18}$

\begin{tabular}{lcccccc}
\hline Sample & $\mathrm{NaNO}_{3}(\mathrm{~g})$ & $\mathrm{Ca}\left(\mathrm{NO}_{3}\right)_{2} \cdot 4 \mathrm{H}_{2} \mathrm{O}(\mathrm{g})$ & $\mathrm{KH}_{2} \mathrm{PO}_{4}(\mathrm{~g})$ & $15.69 \mathrm{M} \mathrm{HNO}_{3}(\mathrm{~mL})$ & Urea & $\mathrm{Ca} / \mathrm{P}(\mathrm{g})$ \\
\hline HA & 5.00 & 1.00 & 0.345 & 0.10 & 1.75 & 1.67 \\
TCP & 5.00 & 1.00 & 0.384 & 0.10 & - & 1.50 \\
Biphasic & 5.00 & 1.00 & 0.345 & 0.10 & 0.075 & 1.67 \\
\hline
\end{tabular}

The present paper reports the in vitro testing of HA, TCP, and biphasic HA-TCP whiskers ${ }^{18}$ by (1) soaking them in replenished SBF solutions for 1 week at $37^{\circ} \mathrm{C}$, and (2) performing live/dead cytotoxicity counts, protein assay, and cell attachment tests by using mouse osteoblasts (7F2).

\section{MATERIALS AND METHODS}

\section{Whisker synthesis}

The details of calcium phosphate whisker preparation were given elsewhere. ${ }^{18}$ Briefly, aqueous solutions containing dissolved $\mathrm{NaNO}_{3}, \mathrm{Ca}\left(\mathrm{NO}_{3}\right)_{2} \cdot 4 \mathrm{H}_{2} \mathrm{O}, \mathrm{KH}_{2} \mathrm{PO}_{4}$, concentrated $\mathrm{HNO}_{3}$, and urea (all reagent-grade, Fisher Chemicals, Fairlawn, NJ) were prepared in $10 \mathrm{~mL}$ of deionized water in 30 mL-capacity Pyre ${ }^{\circledR}$ beakers, as shown in Table I. The first chemical added to the beakers was $\mathrm{NaNO}_{3}$, while the last one was urea. Small aliquots of concentrated $\mathrm{HNO}_{3}$ were added to dissolve back any colloidal precipitates that might have formed following the addition of $\mathrm{Ca}\left(\mathrm{NO}_{3}\right)_{2} \cdot 4 \mathrm{H}_{2} \mathrm{O}$ and $\mathrm{KH}_{2} \mathrm{PO}_{4}$ into the $\mathrm{NaNO}_{3}$ solution. For each case shown in Table I, clear-transparent solutions were thus obtained. Sample beakers were then placed onto $10 \times 10 \times 1 \mathrm{~cm}^{3}$ alumina insulating fiberboards and covered with an upside down 250 mL-capacity glass beaker. To proceed with the synthesis process, the above-mentioned sample assemblies were placed into a household microwave (MW) oven (Sunbeam, max. power $600 \mathrm{~W}, 2.45 \mathrm{GHz}$, Boca Raton, FL) for only 5 min. The MW oven was operated at its maximum power setting. At the end of $5 \mathrm{~min}$ of $\mathrm{MW}$ heating, the sample beakers reached a temperature of about 500 to $550^{\circ} \mathrm{C}$ and were slowly cooled to room temperature (RT), in the MW oven, during the next $20 \mathrm{~min}$.

The substance in the sample beaker was then placed into $500 \mathrm{~mL}$ of deionized water at $\mathrm{RT}\left[(22 \pm 1)^{\circ} \mathrm{C}\right]$ and stirred with a Teflon-coated magnetic fish on a stirrer at around 300 rpm for $1 \mathrm{~h}$, immediately followed by filtration (No. 42 filter paper, Whatman Int., Maidstone, England) in a vacuumassisted Buechner funnel and washing with $2 \mathrm{~L}$ of water. The possible influence of varying the stirring rates on whisker synthesis was not studied. At the end of filtration the effluent solutions were transparent and free of whiskers. Samples were dried overnight at $80^{\circ} \mathrm{C}$ in air.

Apatite-inducing ability of $\mathrm{CaP}$ whiskers were tested by soaking those in a synthetic body fluid (SBF) solution. The details of preparing these solutions were given elsewhere. ${ }^{26}$ Briefly, the SBF solution we used was a Tris/HCl-buffered, $27.0 \mathrm{mM} \mathrm{HCO}{ }_{3}^{-}$ion-containing solution with the ion concentrations given in Table II.

The distinctive characteristic of SBF solutions utilized in this study was that they had the same carbonate ion concentration as that of human blood plasma. In vitro tests were performed in $100 \mathrm{~mL}$-capacity glass bottles, which contained $2 \mathrm{~g}$ of HA, TCP, or biphasic HA-TCP whiskers (in powder form) and $90 \mathrm{~mL}$ of SBF solution. Sealed bottles were kept in an oven at $(37 \pm 1)^{\circ} \mathrm{C}$ for a total duration of 1 week. However, after every $48 \mathrm{~h}$, the used SBF solution was replenished with a fresh one. Recovered samples (after 1 week) were washed with an ample supply of deionized water, followed by drying at $37^{\circ} \mathrm{C}$ for $48 \mathrm{~h}$ in air.

\section{Sample characterization}

Samples were characterized by powder X-ray diffraction (XRD) (XDS 2000, Scintag, Sunnyvale, CA), Fourier-transform infrared spectroscopy (FT-IR) (Nicolet 550, ThermoNicolet, Woburn, MA), field-emission scanning electron microscopy (FESEM) (S-4700, Hitachi, Tokyo, Japan), and inductively-coupled plasma atomic emission spectroscopy (ICP-AES) (61E, Thermo-Jarrell Ash, Woburn, MA) analyses. X-ray diffraction spectra of the SBF-soaked whisker samples were collected (in bulk powder form) over the $2 \theta$ range of $20-45^{\circ}$ by using monochromated $\mathrm{Cu} K \alpha$ radiation $(40 \mathrm{kV}, 30$ $\mathrm{mA}$ ) with a step size of $0.02^{\circ}$ and a preset time of $1 \mathrm{~s}$. XRD

TABLE II

Preparation of SBF Solution $(1 \mathrm{~L})^{26}$

\begin{tabular}{clclcc}
\hline Order & \multicolumn{1}{c}{ Reagent } & Weight $(\mathrm{g})$ & \multicolumn{1}{c}{ Ion } & Human Plasma $(\mathrm{mM})$ & SBF $(\mathrm{mM})$ \\
\hline 1 & $\mathrm{NaCl}$ & 6.547 & $\mathrm{Na}^{+}$ & 142 & 142 \\
2 & $\mathrm{NaHCO}$ & 2.268 & $\mathrm{Cl}^{-}$ & 103 & 125 \\
3 & $\mathrm{KCl}$ & 0.373 & $\mathrm{HCO}_{3}{ }^{-}$ & 27 & 27 \\
4 & $\mathrm{Na}_{2} \mathrm{HPO}_{4} \cdot 2 \mathrm{H}_{2} \mathrm{O}$ & 0.178 & $\mathrm{~K}^{+}$ & 5 & 5 \\
5 & $\mathrm{MgCl}_{2} \cdot 6 \mathrm{H}_{2} \mathrm{O}$ & 0.305 & $\mathrm{Mg}^{2+}$ & 1.5 & 1.5 \\
6 & $\mathrm{CaCl}_{2} \cdot 2 \mathrm{H}_{2} \mathrm{O}$ & 0.368 & $\mathrm{Ca}^{2+}$ & 2.5 & 1 \\
7 & $\mathrm{Na}_{2} \mathrm{SO}_{4}$ & 0.071 & $\mathrm{HPO}_{4}{ }^{2-}$ & 1 & 0.5 \\
8 & $\left(\mathrm{CH}_{2} \mathrm{OH}\right)_{3} \mathrm{CNH}_{2}$ & 6.057 & $\mathrm{SO}_{4}{ }^{2-}$ & 0.5 & 0.5 \\
\hline
\end{tabular}


spectra of the neat whiskers were previously reported elsewhere. ${ }^{18}$ IR data of the SBF-soaked samples were again collected in powder form, and the samples were directly placed onto the diamond ATR holder of the FT-IR spectrometer. This spectrometer was equipped with an Endurance Foundation Series single-bounce diamond ATR $\left(50^{\circ}\right.$ incidence angle), and 32 scans were performed at a resolution of 2 $\mathrm{cm}^{-1}$. SBF-soaked whisker samples were sputter-coated with a thin Pt layer, just prior to imaging with the FESEM, to improve their conductivity. Samples studied by ICP-AES analyses were first dissolved in nitric acid prior to measuring the concentrations of $\mathrm{Ca}, \mathrm{P}, \mathrm{Na}$, and $\mathrm{K}$.

The sizes and dimensions of the synthesized whiskers were measured from the FESEM photomicrographs, and previously reported elsewhere. ${ }^{18}$ The BET surface area of samples (both neat and SBF-soaked whiskers) was determined by applying the standard Brunnauer-Emmet-Teller method to the nitrogen adsorption isotherms obtained at $-196^{\circ} \mathrm{C}$ using a Micromeritics ASAP 2020 instrument (Norcross, GA). Nitrogen adsorption-desorption isotherms were measured at relative pressures between $10^{-2}$ and 1 . Surface area measurements were performed in triplicate.

\section{In vitro tests}

7F2 mouse osteoblast cells (CRL-12557, American Type Culture Collection, Rockville, MD) were grown on $75 \mathrm{~cm}^{2}$ culture flasks at $37^{\circ} \mathrm{C}$ and $5 \% \mathrm{CO}_{2}$ in alpha-minimum essential medium (MEM) with $2 \mathrm{mM} 1$-glutamine and $1 \mathrm{mM}$ sodium pyruvate, without ribonucleosides and deoxyribonucleosides, augmented by $10 \%$ fetal bovine serum (FBS). ${ }^{28}$ The culture medium was changed every other day until the cells reached a confluence of $90-95 \%$, as determined visually by an inverted optical microscope. The cells were then passaged using trypsin (2.5 g/L) EDTA (25 mM) solution (Sigma-Aldrich).

The cells were then seeded at a concentration of 10,000 cells/well on approximately $6 \mathrm{~mm}$ (diameter) $\times 6 \mathrm{~mm}$ (height) cylindrical samples for various assays. Neat whisker powders were compacted in a stainless steel die $(6 \mathrm{~mm}$ diameter) under a constant load of $10 \mathrm{~kg}$, which was applied for $5 \mathrm{~min}$. Sintered $\mathrm{Al}_{2} \mathrm{O}_{3}$ discs were used as the control samples in the cell culture tests.

Cell viability assessment was performed after $72 \mathrm{~h}$ and total protein amounts were measured after 7 days in a 96-well cell culture plate. The medium was replenished after the first day, and then on every $48 \mathrm{~h}$ during the course of the experiments. After the prescribed time period for each test, substrates were rinsed with phosphate-buffered saline (PBS) solution to remove any non-adherent cells.

After 72 h, live/dead cells were counted on the samples. The unattached cells were collected by trypsinization with $0.5 \mathrm{~mL} /$ well trypsin-EDTA solution and were incubated for $10 \mathrm{~min}$. The cells were collected in a conical tube, $1 \mathrm{~mL}$ of media was added and centrifuged for $5 \mathrm{~min}$ at $1000 \mathrm{rpm}$. The pellet formed at the base was resuspended in $1 \mathrm{~mL}$ media. Finally, trypan blue was added and the cells were counted under an optical microscope. Only cells that stain blue were deemed necrotic because of plasma membrane damage.
The total protein assay was measured using $\mathrm{BCA}^{\mathrm{TM}}$ Protein Assay Kit (Pierce Biotechnology, Rockford, IL). A working reagent (WR) was prepared by mixing 50 parts of $\mathrm{BCA}$ Reagent A with 1 part of BCA Reagent B. A $200 \mu \mathrm{L}$ aliquot of the above-mentioned WR was added to each well and thoroughly mixed. Following mixing, the cell culture plate was covered and incubated at $37^{\circ} \mathrm{C}$ for $30 \mathrm{~min}$. The absorbance at $562 \mathrm{~nm}$ was measured with a spectrophotometer at room temperature. A standard curve was prepared by plotting the average blank-corrected $562 \mathrm{~nm}$ measurement for BSA standard versus its concentration in $\mu \mathrm{g} / \mathrm{mL}$. Protein concentration of each sample was then determined by using this standard curve.

Osteoblast attachment and proliferation on the samples were examined by using FESEM. Prior to FESEM investigations, cells were fixed by using 3.5\% glutaraldehyde. The cells were dehydrated with increasing concentrations of ethanol (50, 75, 90, and 100\%) for $10 \mathrm{~min}$ each. Critical point drying was performed according to the previously published procedures. ${ }^{28,29}$ Samples were sputter-coated with a very thin layer of Pt prior to the FESEM imaging at $5 \mathrm{kV}$.

\section{Statistics}

All cell culture experiments were performed in triplicate and the data were expressed as the mean of three experiments. Statistical analyses were performed using SPSS 8.0 software (Chicago, IL). Fisher's Least Significant Difference (LSD) test was used at a confidence level of 95\%, therefore, $p$ values $<0.05$ were considered significant.

\section{RESULTS AND DISCUSSION}

Figures 1(a) and 1(b) display the SEM morphology of the starting $\beta$-TCP (whitlockite) whiskers used in this study. The morphology of HA and biphasic HATCP whiskers were the same as reported previously. ${ }^{18}$ The biphasic whiskers initially contained 60\% TCP and $40 \% \mathrm{HA}$, prior to the SBF-soaking. Inductivelycoupled plasma (ICP-AES) analyses of the starting whiskers of HA, TCP, and biphasic HA-TCP revealed that they contain around $1.5 \mathrm{wt} \% \mathrm{Na}$ and $250 \mathrm{ppm} \mathrm{K}$. With such a presence of alkali ions, it becomes impossible to name these whiskers as fully stoichiometric HA or TCP. The mineralized portion of human bones does not consist of pure $\mathrm{Ca}_{10}\left(\mathrm{PO}_{4}\right)_{6}(\mathrm{OH})_{2}$, rather it contains elements like $\mathrm{Na}^{+}, \mathrm{K}^{+}$, and $\mathrm{Mg}^{2+}$ up to the significant level of $1.3 \mathrm{wt} \% .{ }^{15}$ Bone mineral is also rich in carbonate ions, that is, $5.8 \mathrm{wt} \%$ of its total weight. ${ }^{15}$

The SEM photomicrographs of Figure 2 depict the morphology of TCP, HA-TCP, and HA whiskers after being soaked in the SBF solution at $37^{\circ} \mathrm{C}$ for 1 week. After SBF soaking, the initial [see Figs. 1(a) and 1(b)] whisker morphology significantly changed. The new surface morphology resembled those of biomimetic 


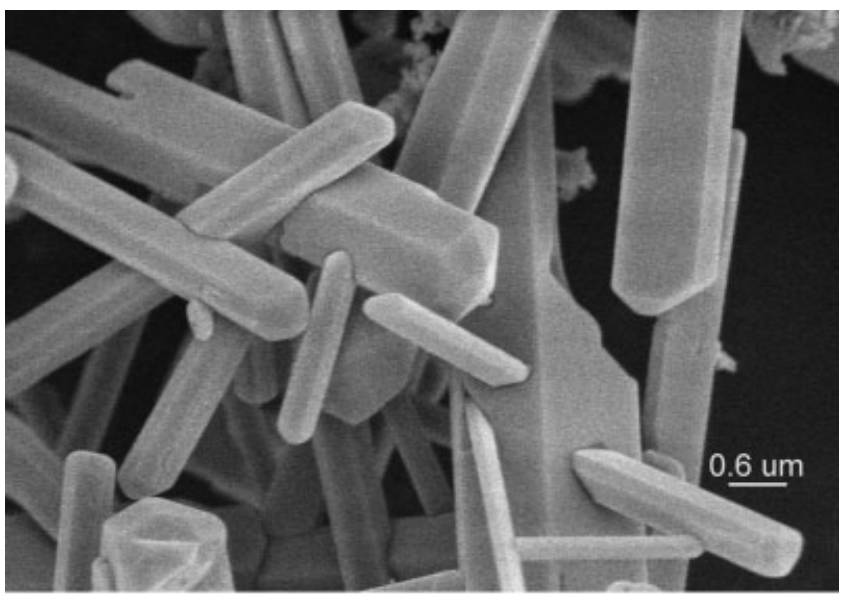

(a)

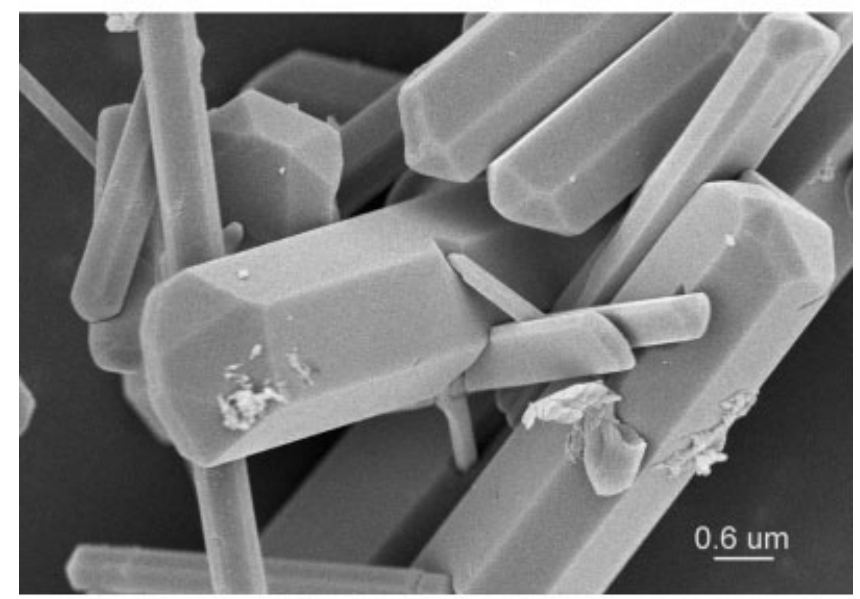

(b)

Figure 1. FESEM photomicrographs of $\beta$-TCP whiskers

CaPs grown in an SBF solution on Ti6Al4V strips or the in situ $\mathrm{CaP}$ precipitates formed in SBF solutions. ${ }^{30}$ The BET surface areas of neat and SBF-soaked CaP whiskers are reported in Table III. The highest experimental surface area value measured for the SBFsoaked TCP whiskers corresponded very well with the highest nanoroughness/nanotexture visually observed for these samples [compare Fig. 2(b) with Figs. 2(d) and 2(f)].

Powder X-ray diffraction and FT-IR data for the SBF-soaked whiskers are given in Figures 3 and 4, respectively. Prior to collecting these XRD and FT-IR data, the SBF-soaked whiskers (2 g in each SBF-soaking bottle) were ground into a fine powder by using an agate mortar and a pestle. The XRD and FT-IR data presented in Figures 3 and 4, therefore, were not limited only to the surfaces of the whiskers. According to the XRD data, TCP whiskers almost completely transformed into apatitic calcium phosphates (Fig. 3) after one week of soaking in the synthetic body fluid. Since SBF solutions can only form apatitic CaP (but not
TCP), neat HA whiskers soaked in SBF solutions again yielded characteristic HA diffraction patterns (Fig. 3). On the other hand, XRD peaks for crystalline $\beta$-TCP were still visible in the SBF-soaked biphasic HA-TCP samples.

FT-IR data of Figure 4 revealed the presence of $\mathrm{CO}_{3}{ }^{2-}\left(1480-1420\right.$ and $\left.873 \mathrm{~cm}^{-1}\right)$ and $\mathrm{HPO}_{4}{ }^{2-}$ groups $\left(870,1133\right.$ and $\left.1210 \mathrm{~cm}^{-1}\right)$ in all the SBF-soaked samples. ${ }^{31}$ Most of the time it may become somewhat difficult to distinguish between the resembling FT-IR spectra of $\beta$-TCP and HA, and for this purpose the FT-IR trace of single phase $\beta$-TCP $(>99 \%$, Fluka) powders is presented here in Figure 5. For $\beta$-TCP, there were no absorption bands present over the range 4000 and $1300 \mathrm{~cm}^{-1}$. It is visible from Figure 5 that there are at least 25 absorption bands in the characteristic FT-IR trace of pure $\beta$-TCP samples.

Relying on the experimental solubility values of some of the calcium phosphate phases reported by Tang et al., ${ }^{32}$ it is seen that the dissolution rate of $\beta$-TCP (i.e., $\left.1.26 \times 10^{-4} \mathrm{~mol} /\left(\mathrm{m}^{-2} \mathrm{~min}^{-1}\right)\right)$ in an aqueous solution at a $\mathrm{pH}$ of about 6 is about 89 times greater than that of carbonated apatite, $1.42 \times 10^{-6}$ $\mathrm{mol} /\left(\mathrm{m}^{-2} \mathrm{~min}^{-1}\right)$. According to this, it is not difficult to assume that the whiskers of $\beta$-TCP of this study would dissolve in the SBF solution (in 1 week, at $37^{\circ} \mathrm{C}$ ) at a much faster rate than those of HA. The dissolution of $\beta$-TCP in aqueous solutions can be described by the following reaction

$$
\begin{aligned}
& 3 \mathrm{Ca}_{3}\left(\mathrm{PO}_{4}\right)_{2}(\mathrm{~s})+\mathrm{H}_{2} \mathrm{O} \rightarrow 9 \mathrm{Ca}^{2+}(\mathrm{aq}) \\
& +\mathrm{HPO}_{4}{ }^{2-}(\mathrm{aq})+5 \mathrm{PO}_{4}{ }^{3-}(\mathrm{aq})+\mathrm{OH}^{-}(\mathrm{aq})
\end{aligned}
$$

During the dissolution of $\beta$-TCP, the above aqueous ions combine to form what is known as calcium-deficient hydroxyapatite $(\mathrm{CDHA}), \mathrm{Ca}_{9}(\mathrm{OH})\left(\mathrm{HPO}_{4}\right)\left(\mathrm{PO}_{4}\right)_{5} \cdot{ }^{33}$ CDHA can also incorporate $\mathrm{CO}_{3}{ }^{2-}$ ions, and it lacks one $\mathrm{Ca}^{2+}$ and one $\mathrm{OH}^{-}$in the unit cell of its crystal structure. CDHA yields the same XRD pattern with that of stoichiometric hydroxyapatite, HA.

The bottom XRD trace shown in Figure 3, thus, belonged to the newly formed CDHA on and along with the initial TCP whiskers, prior to their total consumption during the process, and this pattern was difficult to differentiate from that of HA. The original $\beta$-TCP whiskers, in a sense, behaved like a "guiding scaffold" for the formation or regeneration of nanotextured $\mathrm{CaPs}$ with a rod-like morphology. The detection of $\mathrm{HPO}_{4}{ }^{2-}$ bands in the FT-IR data of Figure 4 also confirmed the formation of carbonated CDHA after soaking the whiskers in $\mathrm{SBF} .{ }^{34}$ Such non-stoichiometric, carbonated apatitic calcium phosphates can readily accommodate a $\mathrm{Ca} / \mathrm{P}$ molar ratio between 1.67 and 1.33 (i.e., octacalcium phosphate, OCP, $\mathrm{Ca}_{8} \mathrm{H}_{2}\left(\mathrm{PO}_{4}\right)_{6}\left(5 \mathrm{H}_{2} \mathrm{O}\right)$. OCP is an acidic calcium phosphate salt, and the formation of it in neutral aqueous 


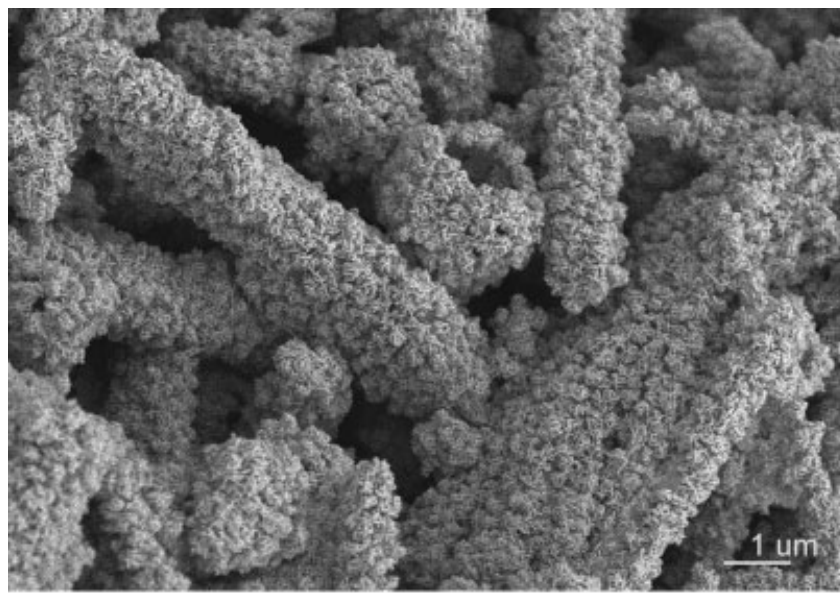

(a)

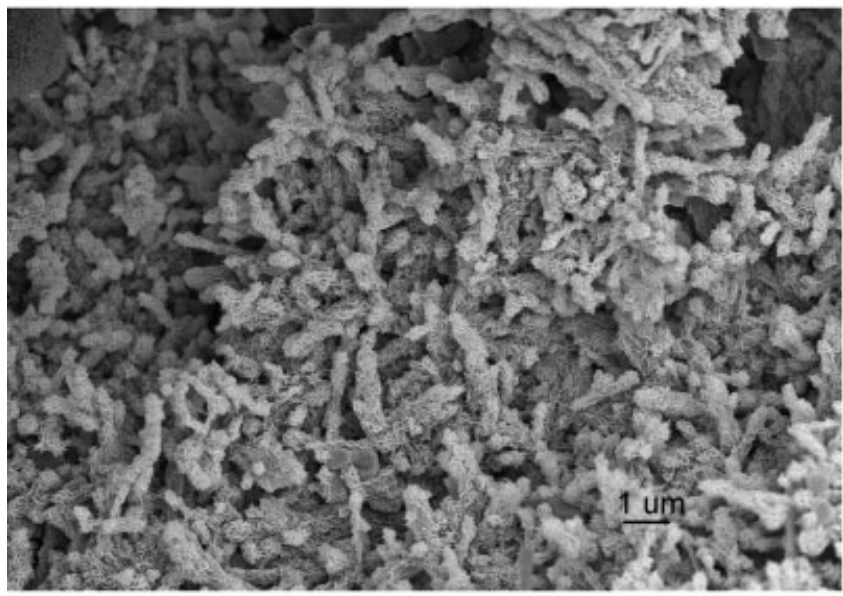

(c)

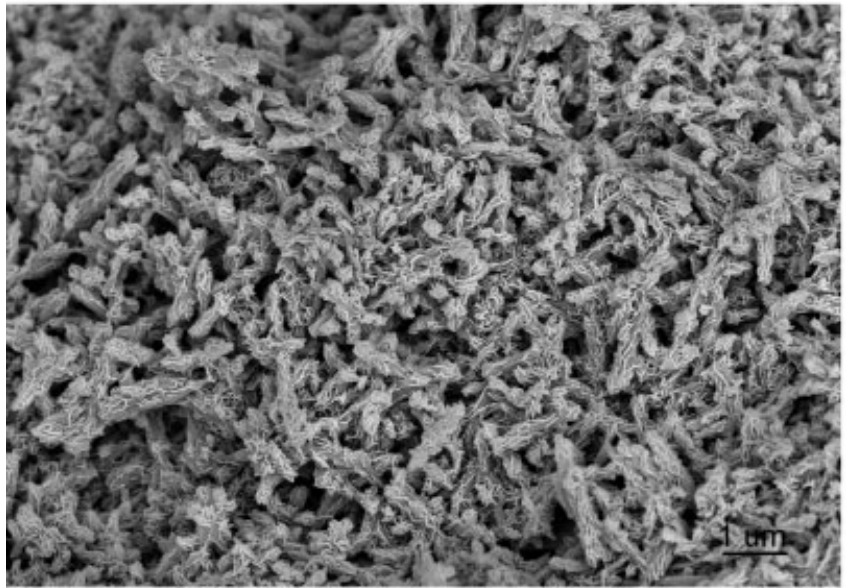

(e)

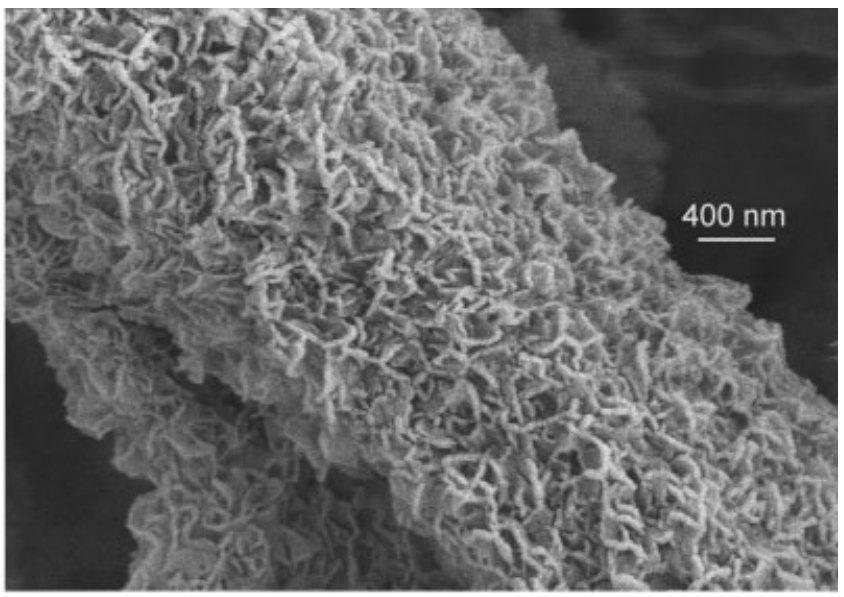

(b)

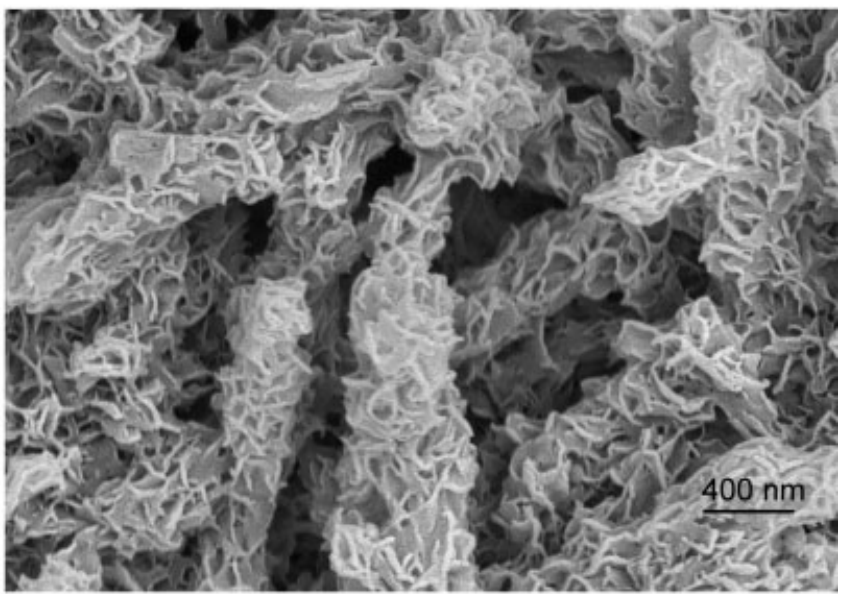

(d)

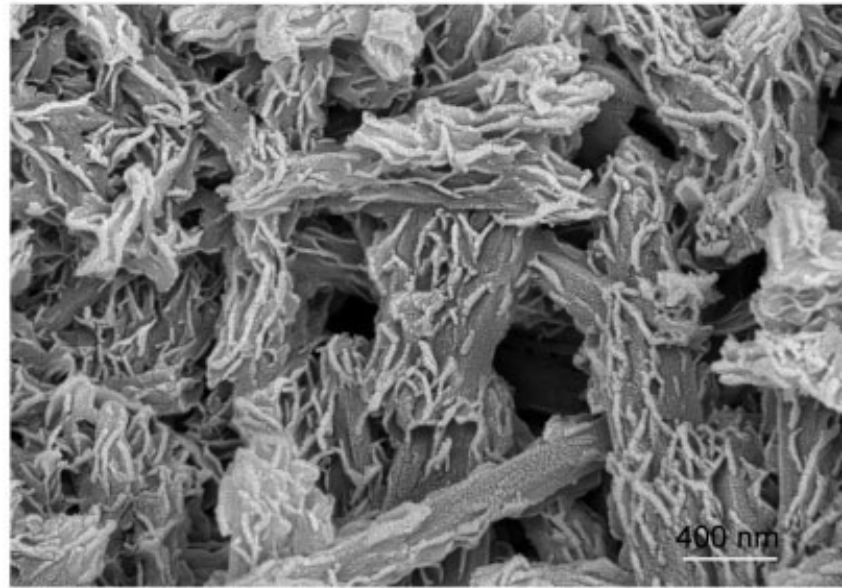

(f)

Figure 2. FESEM photomicrographs of SBF-soaked whiskers: $\beta$-TCP whiskers $(a, b)$; biphasic HA-TCP whiskers (c,d); HA whiskers $(\mathrm{e}, \mathrm{f})$.

solutions of $\mathrm{pH} 7.4$ (such as SBF) is quite difficult, if not impossible. The strongest XRD reflection for the OCP phase is to be detected at $d$-spacing $=18.703 \AA$; however, the XRD data (those scanned that range) of the SBF-soaked whiskers of this study did not exhibit this peak.

SBF solutions are supersaturated with respect to apatitic calcium phosphate nucleation because of their 
TABLE III

BET Surface Areas of Samples

\begin{tabular}{lc}
\hline \multicolumn{1}{c}{ Sample } & Surface Area $\left(\mathrm{m}^{2} / \mathrm{g}\right)^{\mathrm{a}}$ \\
\hline Neat HA & $8.7 \pm 0.4$ \\
Neat biphasic HA-TCP & $4.4 \pm 0.2$ \\
Neat TCP & $3.1 \pm 0.2$ \\
SBF-soaked HA & $45.0 \pm 1.6$ \\
SBF-soaked biphasic HA-TCP & $56.9 \pm 2.1$ \\
SBF-soaked TCP & $112.2 \pm 2.5$ \\
\hline
\end{tabular}

${ }^{\mathrm{a}}$ Mean values of 3 runs \pm SD.

high Ca/P molar ratio (2.5), and therefore, even when they are optically transparent, they contain calcium phosphate clusters with sizes around $10 \AA .^{35}$ These $\mathrm{CaP}$ clusters were first described by Betts and Posner ${ }^{36}$ to have the $\mathrm{Ca}_{9}\left(\mathrm{PO}_{4}\right)_{6}$ stoichiometry, and are known as Posner clusters. These clusters present in the SBF solutions aggregate to produce the biomimetic $\mathrm{CaP}$ nanotexture, while filling the intercluster spaces with water and bicarbonate molecules. Dorozhkina and Dorozhkin $^{37}$ quantitatively confirmed the carbonated nature of such clusters when the clusters reached the micron-size range.

Dissolution of $\beta$-TCP provided the SBF solution, at the dissolution interface, with the aqueous ions given in Eq. (1), and we speculate that the presence of these ions triggered the hexagonal packing of Posner clusters $^{35}$ present in the SBF to form petal- or flake-like, apatitic calcium phosphates on the whiskers [Figs. 2(a) and 2(b)]. When HA was present as a phase, either in pure HA or biphasic HA-TCP samples, in those whiskers (since it had a significantly lower solubility in comparison with $\beta$-TCP), the supply of those ions to the solution was reduced. This was probably why the XRD traces (Fig. 3) of biphasic HA-TCP still contained peaks of $\beta$-TCP. In the case of pure HA whiskers [Figs.

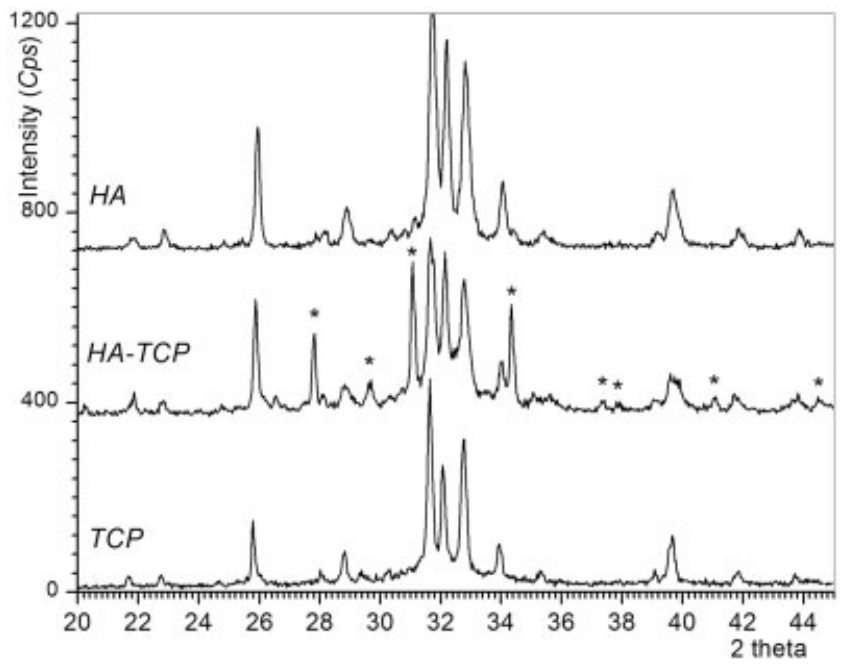

Figure 3. XRD traces of SBF-soaked whiskers (* denotes $\beta$-TCP peaks).

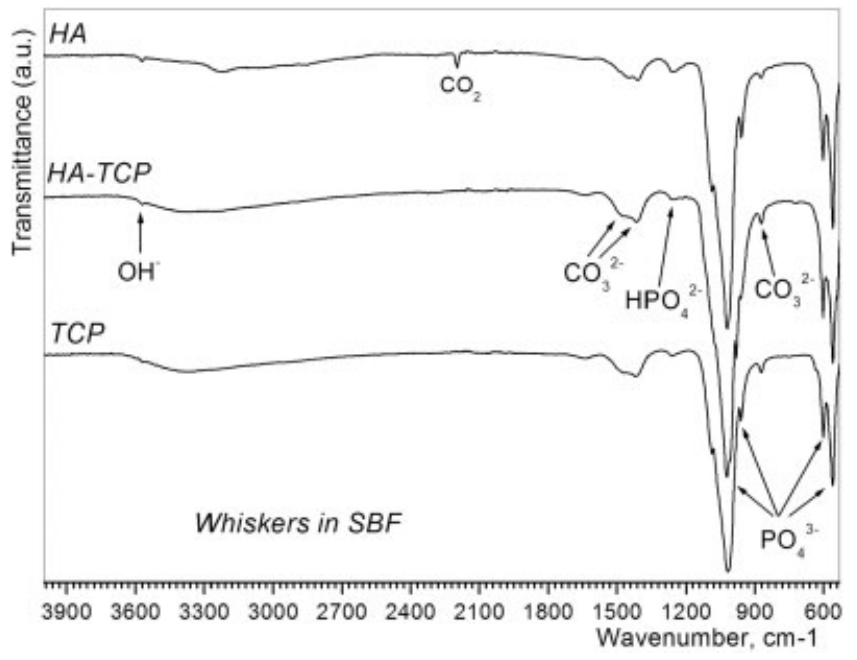

Figure 4. FT-IR traces of SBF-soaked whiskers.

2(e) and 2(f)], the formation of the CaP nanotexture was less pronounced when compared with those of $\beta$-TCP whiskers [Figs. 2(a) and 2(b)], probably due to their almost two order of magnitude lower solubility. Biphasic HA-TCP whiskers had taken an intermediate place in between the pure TCP and pure HA samples, in terms of the extent of forming that $\mathrm{CaP}$ nanotexture [see Figs. 2(a) through 2(f)].

The characteristic surface morphology of the neatwhisker cylinders $(6 \mathrm{~mm} \times 6 \mathrm{~mm})$ on which the osteoblast cells were cultured is given in the SEM micrograph of Figure 6. As a result of the pressing action, whiskers formed a porous compact while maintaining their individual shapes. Mouse osteoblast cells (7F2) cultured on compacted whisker samples (as is, neat, not soaked in SBF) exhibited differences in terms of the number of attached cells and protein concentration, as presented in Figures 7(a) and 7(b). The highest values of attached cells and the protein

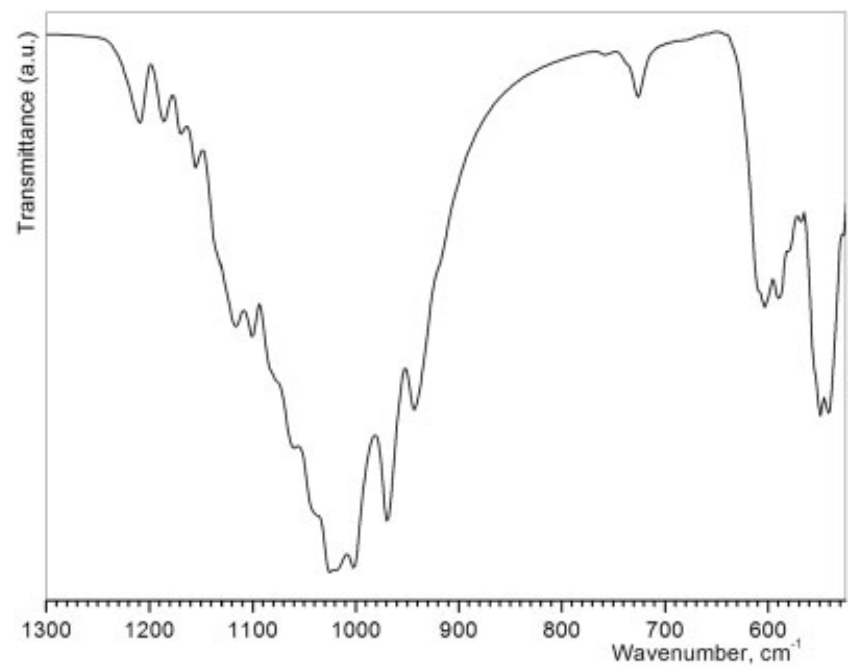

Figure 5. FT-IR trace of pure $\beta$-TCP powders. 


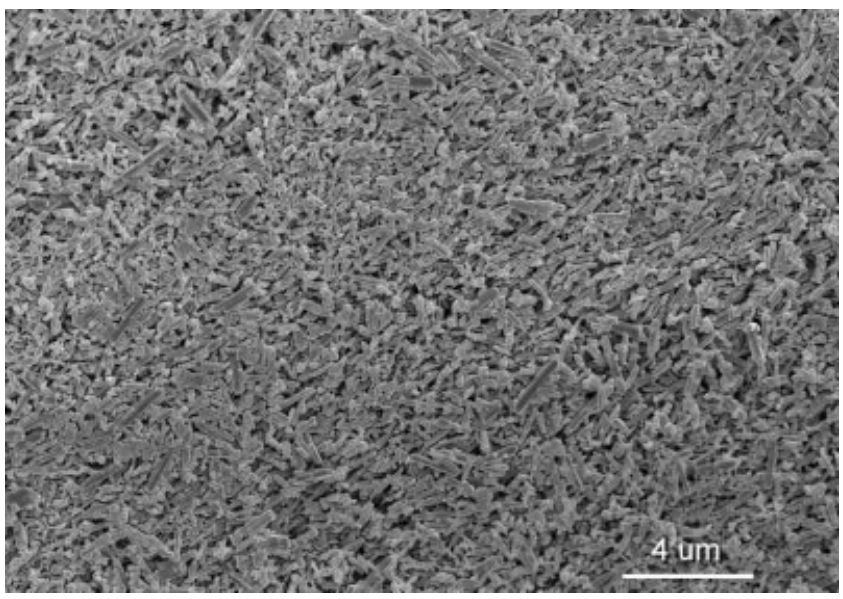

Figure 6. FESEM micrograph of the surface of whisker cylinders used in cell culture tests.

concentrations were observed for HA whisker compacts.

The results of the Fisher's least significant difference (LSD) test are shown in Table IV. LSD test is basically a student's $t$ test using a pooled error variance, and is suitable for making pair-wise comparisons among a set of $t$ population means. In Table IV, $p$ values less than 0.05 indicated that there was a statistically meaningful and reliable difference. In other words, the cell attachment and protein concentrations registered for the $\mathrm{Al}_{2} \mathrm{O}_{3}$ control samples were statistically different than those of all the CaPs of this study.

At the significance level of 0.05 , when TCP was compared with HA in terms of cell attachment and total protein concentration, the $p$ values for both LSD tests came out to be less than 0.05 (as shown in Table IV). Therefore, we are $95 \%$ confident that there is a difference in cell viability and total protein concentration between HA and TCP whisker compacts. However, it was not possible to detect any statistical difference between HA-TCP and TCP or HA-TCP and $\mathrm{HA}$ in terms of number of cells attached and protein concentration.

Osteoblast attachment and proliferation on the surfaces of whisker compacts was evaluated by FESEM, and given in Figures 8(a)-8(f). Osteoblasts were attached to the surfaces of all the whisker compacts tested here; however, the high-magnification micrographs showed slight differences in osteoblast proliferation.

Osteoblast behavior is sensitive to the biochemical and topographical features (i.e., chemical and physical microarchitecture) of their substrate. The ideal and most preferred surface used by osteoblasts in vivo is the osteoclast resorption pits. ${ }^{38}$ The cell attachment and the protein assay histograms given in Figures 7(a) and $7(\mathrm{~b})$ clearly showed that the $\mathrm{CaP}$ whisker compacts always performed better than the control sam- ples of sintered, dense $\mathrm{Al}_{2} \mathrm{O}_{3}$. Mouse osteoblasts were also able to differentiate between the chemical composition of the $\mathrm{CaP}$ whiskers [Figs. 7(a) and 7(b)]. In other words, osteoblasts favored whiskers of hydroxyapatite (HA) than those of over $\beta$-TCP or biphasic HA-TCP. It is a well-known fact that the surface chemistry of a material determines the initial in vitro interactions of proteins, such as fibronectin with integrin cell-binding domains, which in turn regulate the cell adhesion process. Osteoblast response to the $\mathrm{CaP}$ surfaces of this study can be regarded as the sum of their ability to attach, proliferate, and differentiate. In the attachment stage, osteoblast filopodia explore the substrate topography for areas to which a greater surface area of the cell can adhere. These filopodia are used in sensing the substrate, and they extend over significant distances to find areas appropriate for attachment. ${ }^{39}$ The FESEM micrographs of Figure 8 revealed these extended filopodia and their attachment to the individual whiskers in the whisker compact used in the in vitro tests.

Cells are known to extend fewer filopodia while still

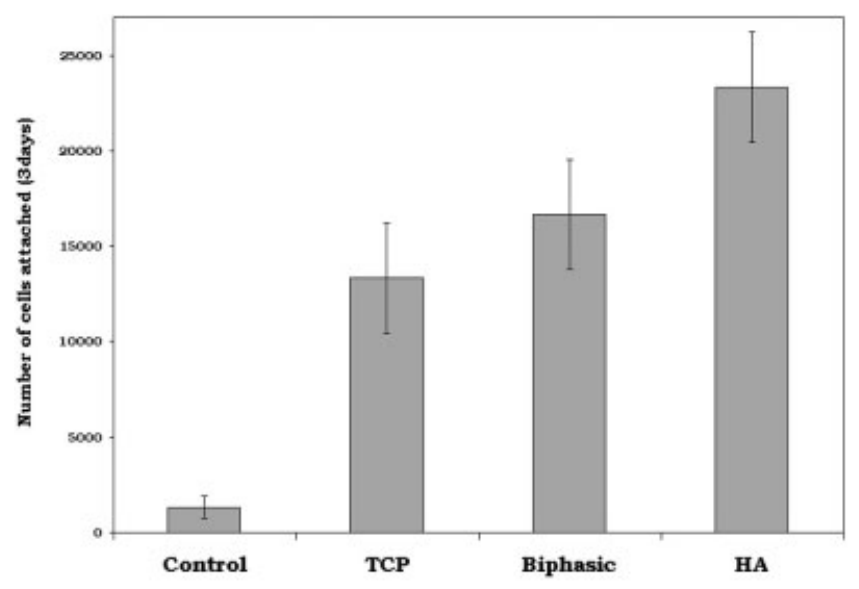

(a)

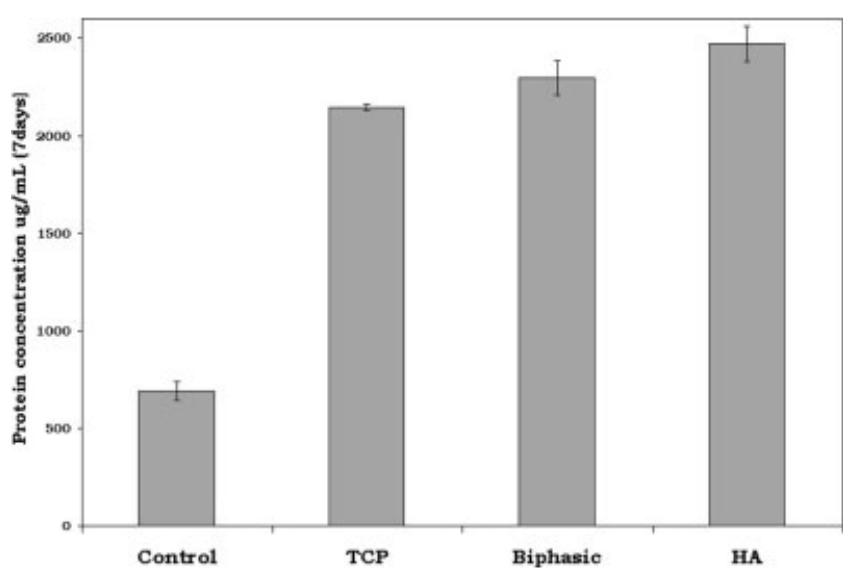

(b)

Figure 7. (a) Number of cells on whiskers (control: $\mathrm{Al}_{2} \mathrm{O}_{3}$ ). (b) Protein assays for whiskers (control: $\mathrm{Al}_{2} \mathrm{O}_{3}$ ). 
TABLE IV

$p$ Values for the Number of Cells Attached and Protein Concentration

\begin{tabular}{|c|c|c|c|c|c|}
\hline Test & & Control & HA & HA-TCP & TCP \\
\hline \multirow[t]{5}{*}{ No. of cells attached } & Control & - & $0.001^{*}$ & $0.006^{*}$ & $0.019^{*}$ \\
\hline & $\mathrm{HA}$ & $0.001^{*}$ & - & 0.143 & $0.041^{*}$ \\
\hline & HA- & & & & \\
\hline & TCP & $0.006^{*}$ & 0.143 & - & 0.441 \\
\hline & TCP & $0.019^{*}$ & $0.041^{*}$ & 0.441 & - \\
\hline \multirow[t]{5}{*}{ Total protein concentration } & Control & - & $0^{*}$ & $0^{*}$ & $0^{*}$ \\
\hline & HA & $0^{*}$ & - & 0.159 & $0.019^{*}$ \\
\hline & HA- & & & & \\
\hline & TCP & $0^{*}$ & 0.159 & - & 0.202 \\
\hline & TCP & $0^{*}$ & $0.019^{*}$ & 0.202 & - \\
\hline
\end{tabular}

Control $=\mathrm{Al}_{2} \mathrm{O}_{3}$.

in the process of migration than once permanently settled in place. ${ }^{40}$ Sun et al. ${ }^{41}$ exposed cells to calcium phosphate particles and reported that HA particles $(100 \mathrm{~nm})$ or $\beta$-TCP particles $(100 \mathrm{~nm})$ inhibited the growth of primary mouse osteoblasts, while causing an increase in their expression of alkaline phosphatase ${ }^{42}$ In addition, Pioletti et al. ${ }^{43}$ observed a decrease in growth, viability, and synthesis of extracellular matrix $(\mathrm{ECM})$ in primary mouse osteoblasts that were exposed to $\beta$-TCP particles $(1-10 \mu \mathrm{m})$ or $\mathrm{CaHPO}_{4} \cdot 2 \mathrm{H}_{2} \mathrm{O}$ particles $(1-10 \mu \mathrm{m})$. A $90 \%$ decrease in viability was reported by Pioletti et al. ${ }^{43}$ when evaluated using a Live-Dead assay similar to what we have used in this study. Our results with the $\beta$-TCP whisker compacts [Figs. 8(a) and 8(b)] also confirmed the findings of Pioletti et al. ${ }^{43}$ The bone depositing cells (i.e., osteoblasts) always prefer more basic surfaces to attach and proliferate, and this was also confirmed in the present study. The surface basicity of the whisker compacts increased in going from $\beta$-TCP (neutral $\mathrm{pH}$ ) to HA ( $\mathrm{pH}>9)$. The $\mathrm{pH}$ values of as-synthesized whiskers were measured, at $37^{\circ} \mathrm{C}$, by inserting a $\mathrm{pH}$ electrode into suspensions prepared by adding $1 \mathrm{~g}$ of whiskers into $5 \mathrm{~mL}$ deionized water, and after keeping the whiskers in these for $15 \mathrm{~min}$. The micrographs of Figures 8(c)-8(f) also confirmed the increasing number of cells attached on the whisker compacts containing HA phase [i.e., biphasic HA-TCP, Figs. 8(c) and 8(d) and pure HA, Figs. 8(e) and 8(f)] when compared with that on pure TCP [Figs. 8(a) and 8(b)]. The visual cell attachment and proliferation information depicted in the micrographs of Figure 8 was also found to be in agreement with the cell culture data presented in Figure 7.

$\mathrm{CaP}$ particles and other bioactive materials have been used as fillers in polymer-based bone cements to improve their mechanical properties. ${ }^{44-47} \mathrm{SiC}$ whiskers were also used as fillers, for instance, to reinforce Bis-GMA-based dental resins to extend their use to large load-bearing restorations. ${ }^{20}$ The $\mathrm{SiC}$ whiskers possessed a high structural perfection resulting in su- perior strength values. While plain whiskers did not significantly strengthen the resin matrix, silica coating (on the whiskers) was reported ${ }^{48}$ to roughen the whisker surfaces and enhanced whisker retention in the matrix, resulting in strong composites with substantially increased strength and toughness. Nevertheless, even calcium carbide "ceramic" particles are not resorbable in vivo, and their cytotoxicity behavior, in case they go into the bloodstream of a patient and possibly end up in kidneys and/or liver are not known at all. ${ }^{49}$

The SBF-soaked $\beta$-TCP, biphasic HA-TCP, and HA whiskers reported in this study were found to possess high BET surface area values, in comparison with neat whiskers of the same compositions. Our research on the incorporation of SBF-soaked whiskers having such a special surface topography into biopolymer matrices, such as cross-linked gelatin, keratin or alginates, is in progress, which we plan to report in due time.

\section{CONCLUSIONS}

(1) Whiskers of $\beta$-TCP, biphasic HA-TCP, and HA have been synthesized by using a microwaveassisted molten salt synthesis procedure. ${ }^{13}$

(2) Upon soaking in synthetic body fluid (SBF) solutions for 1 week at $37^{\circ} \mathrm{C}$, all the whiskers of this study were observed to form petal- or flake-like CaPs on their surfaces, while still retaining their global whisker-like shapes.

(3) SBF-soaking of CaP whiskers of this study increased their experimental BET surface areas from single-digit values to about $45-112 \mathrm{~m}^{2} / \mathrm{g}$.

(4) In vitro cell culture tests performed with the mouse osteoblasts (7F2) on the neat whisker compacts showed decreasing number of cells attached and protein concentration values in the following order: HA > biphasic HA-TCP $>$ $\beta$-TCP. 

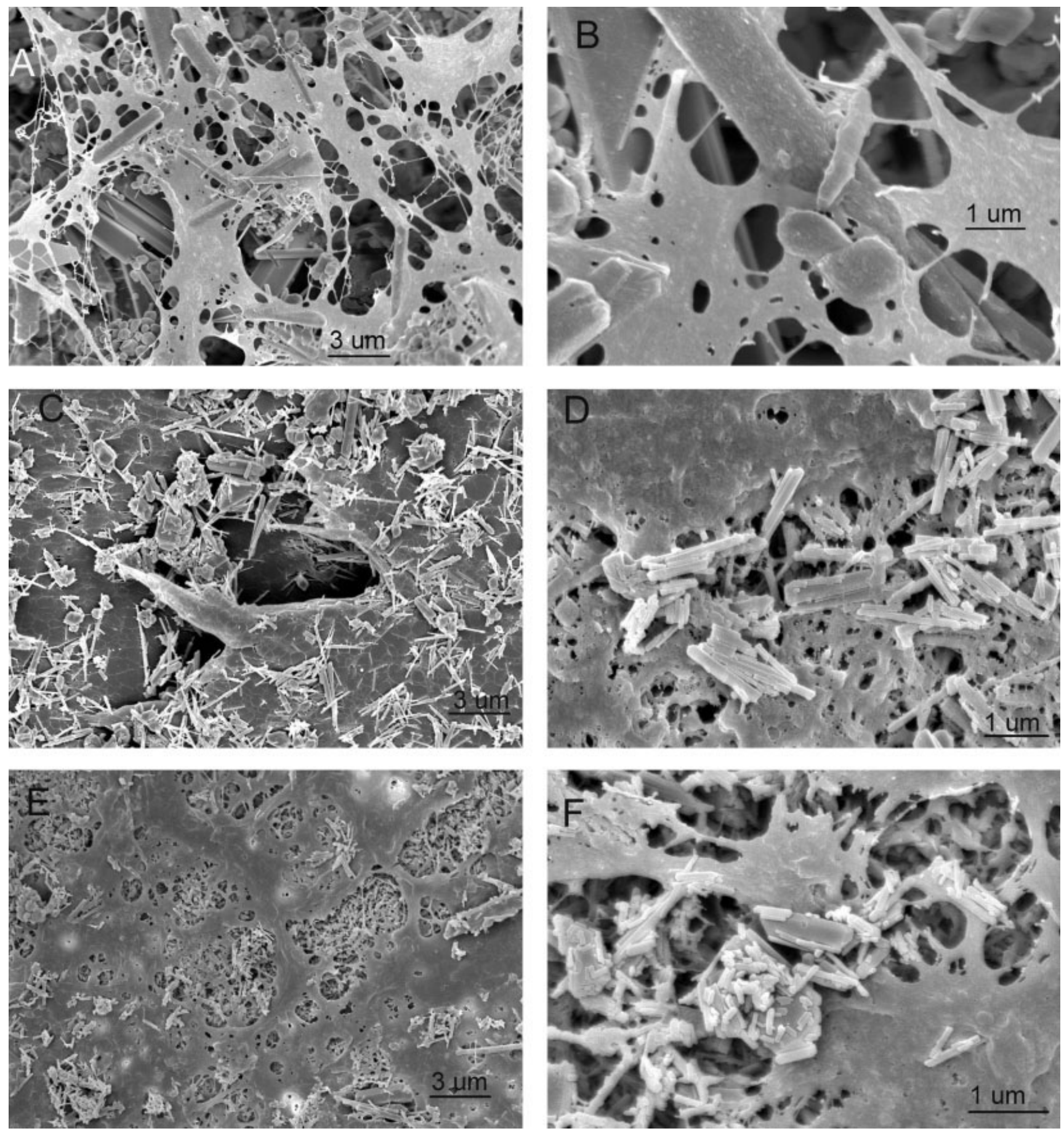

Figure 8. FESEM photomicrographs of osteoblast proliferation on whiskers: $\beta$-TCP whiskers (a,b); biphasic HA-TCP whiskers (c,d); HA whiskers (e,f).

This work was a part of the M.Sc. Dissertation of Mr. Sahil Jalota.

\section{References}

1. Yoshimura M, Suda H, Okamoto K, Ioku K. Hydrothermal synthesis of biocompatible whiskers. J Mater Sci 1994;29:3399-3402.
2. Romundstad P, Andersen A, Haldorsen T. Cancer incidence among workers in the Norwegian silicon carbide industry. Am J Epidemiol 2001;153:978-986.

3. Vaughan GL, Trently SA. The toxicity of silicon carbide whiskers. A review. J Environ Sci Health A 1996;31:2033-2054.

4. Johnson NF, Hahn FF. Induction of mesothelioma after intrapleural inoculation of F344 rats with silicon carbide whiskers or continuous ceramic filaments. Occup Environ Med 1996;53:813-816. 
5. Warheit DB. A review of some biophysical factors and their potential roles in the development of fiber toxicity. Regul Toxicol Pharmacol 1994;20:S113-S120.

6. Kasuga T, Inoue T, Tsuji K, Ota Y, Abe Y. Preparation of porous ceramics with calcium metaphosphate fiber skeleton for biomedical use. J Am Ceram Soc 1995;78:245-247.

7. Suchanek W, Suda H, Yashima M, Kakihana M, Yoshimura M. Biocompatible whiskers with controlled morphology and stoichiometry. J Mater Res 1995;10:521-529.

8. Kundu PK, Waghode TS, Bahadur D, Datta D. Cell culture approach to biocompatibility evaluation of unconventionally prepared hydroxyapatite. Med Biol Eng Comput 1998;36:654-658.

9. Suchanek W, Yoshimura M. Preparation of fibrous, porous hydroxyapatite ceramics from hydroxyapatite whiskers. J Am Ceram Soc 1998;81:765, 767.

10. Tas AC. Molten salt synthesis of calcium hydroxyapatite whiskers. J Am Ceram Soc 2001;84:295-300.

11. Jinawath S, Pongkao D, Suchanek W, Yoshimura M. Hydrothermal synthesis of monetite and hydroxyapatite from monocalcium phosphate monohydrate. Int J Inorg Mater 2001;3:997-1001.

12. Park HC, Baek DJ, Park YM, Yoon SY, Stevens R. Thermal stability of hydroxyapatite whiskers derived from the hydrolysis of $\alpha$-TCP. J Mater Sci 2004;39:2531-2534.

13. Iizuka T, Nozuma A. Effects of the buffer solutions on the growth of hydroxyapatite whiskers. J Ceram Soc Jpn 1999;107: 442-448.

14. Toyama T, Oshima A, Yasue T. Hydrothermal synthesis of hydroxyapatite whisker from amorphous calcium phosphate and the effect of carboxylic acid. J Ceram Soc Jpn 2001;109:232-237.

15. Hench LL. Bioceramics: From concept to clinic. J Am Ceram Soc 1991;74:1487-1510.

16. Yeni YN, Brown CU, Norman TL. Influence of bone composition and apparent density on fracture toughness of the human femur and tibia. Bone 1998;22:79-84.

17. Phelps JB, Hubbard GB, Wang X, Agrawal CM. Microstructural heterogeneity and the fracture toughness of bone. J Biomed Mater Res 2000;51:735-741.

18. Jalota S, Tas AC, Bhaduri SB. Microwave-assisted synthesis of calcium phosphate nanowhiskers. J Mater Res 2004;19:18761881.

19. Suchanek W, Yashima M, Kakihana M, Yoshimura M. Processing and mechanical properties of hydroxyapatite reinforced with hydroxyapatite whiskers. Biomaterials 1996;17:1715-1723.

20. Aizawa M, Porter AE, Best SM, Bonfield W. Ultrastructural observation of single-crystal apatite fibers. Biomaterials 2005; 26:3427-3433.

21. Xu HHK, Smith DT, Simon CG. Strong and bioactive composites containing nano-silica-fused whiskers for bone repair. Biomaterials 2004;25:4615-4626

22. $\mathrm{Xu} \mathrm{HHK}$. Long-term water-ageing of whisker-reinforced polymer-matrix composites. J Dent Res 2003;82:48-52.

23. Xu HHK, Quinn JB. Whisker-reinforced bioactive composites containing calcium phosphate cement fillers: Effects of filler ratio and surface treatments on mechanical properties. J Biomed Mater Res 2001;57:165-174.

24. Park K, Sundaresan S, Vasilos T, Sung C. SiC whisker-reinforced and C fiber-reinforced calcium phosphate composites. J Mater Res 1994;9:2476-2479.

25. Kokubo T. Surface chemistry of bioactive glass-ceramics. J Non-Cryst Solids 1990;120:138-151.

26. Bayraktar D, Tas AC. Chemical preparation of carbonated calcium hydroxyapatite powders at $37^{\circ} \mathrm{C}$ in urea-containing synthetic body fluids. J Eur Ceram Soc 1999;19:2573-2579.

27. Oyane A, Kim HM, Furuya T, Kokubo T, Miyazaki T, Nakamura T. Preparation and assessment of revised simulated body fluids. J Biomed Mater Res A 2003;65:188-195.

28. Webster TJ, Siegel RW, Bizios R. Osteoblast adhesion on nanophase ceramics. Biomaterials 1999;20:1221-1227.
29. Webster TJ, Ejiofor JU. Increased osteoblast adhesion on nanophase metals: Ti, Ti6Al4V, CoCrMo. Biomaterials 2004;25: 4731-4739.

30. Tas AC, Bhaduri SB. Rapid coating of Ti6Al4V at RT with a calcium phosphate solution similar to 10x simulated body fluid. J Mater Res 2004;19:2742-2749.

31. Tamai M, Nakamura M, Isshiki T, Nishio K, Endoh H, Nakahira A. A metastable phase in thermal decomposition of Ca-deficient hydroxyapatite. J Mater Sci Mater Med 2003;14:617-622.

32. Tang R, Hass M, Wu W, Gulde S, Nancollas GH. Constant composition dissolution of mixed phases. II. Selective dissolution of calcium phosphates. J Colloid Interface Sci 2003;260:379-384.

33. Li YB, Zhang XD, de Groot K. Hydrolysis and phase transition of $\alpha$-tricalcium phosphate. Biomaterials 1997;18:737-741.

34. Kokubo T, Himeno T, Kim HM, Kawashita M, Nakamura T. Process of bonelike apatite formation on sintered hydroxyapatite in serum-containing SBF. Key Eng Mater 2004;254-256: 139-142.

35. Onuma K, Ito A. Cluster growth model for hydroxyapatite. Chem Mater 1998;10:3346-3351.

36. Betts F, Posner AS. A structural model for amorphous calcium phosphate. Trans Am Cryst Assoc 1974;10:73-84.

37. Dorozhkina EI, Dorozhkin SV. Structure and properties of the precipitates formed from condensed solutions of the revised simulated body fluid. J Biomed Mater Res A 2003;67:578-581.

38. Boyan BD, Schwartz Z, Lohmann CH, Sylvia VL, Cochran DL, Dean DDD, Puzas JE. Pretreatment of bone with osteoclasts affects phenotypic expression of osteoblast-like cells. J Orthop Res 2003;4:638-647.

39. Rea SM, Brooks RA, Schneider A, Best SM, Bonfield W. Osteoblast-like cell response to bioactive composites surface-topography and composition effects. J Biomed Mater Res B 2004;70: 250-261.

40. Dalby MJ, Di Silvio L, Davies GW, Bonfield W. Surface topography and HA filler volume effect on primary human osteoblast in vitro. J Mater Sci Mater Med 2000;12:805-810.

41. Sun JS, Tsuang YH, Liao CJ, Liu HC, Hang YS, Lin FH. The effects of calcium phosphate particles on the growth of osteoblasts. J Biomed Mater Res 1997;37:324-334.

42. Simon CG, Guthrie WF, Wang FW. Cell seeding into calcium phosphate cement. J Biomed Mater Res A 2004;68:628-639.

43. Pioletti DP, Takei H, Lin T, Landuyt PV, Ma QJ, Kwon SY, Sung KLP. The effects of calcium phosphate cement particles on osteoblast functions. Biomaterials 2000;21:1103-1114.

44. Dupraz AMP, de Wijn JR, van de Meer SAT, de Groot K. Characterization of silane-treated hydroxyapatite powders for use as filler in biodegradable composites. J Biomed Mater Res 1996;30:231-238.

45. Greish YE, Brown PW. Characterization of bioactive glassreinforced HAP-polymer composites. J Biomed Mater Res 2000;52:687-694.

46. Harper EJ, Braden M, Bonfield W. Mechanical properties of hydroxyapatite reinforced poly(ethylmethacrylate) bone cement after immersion in a physiological solution: Influence of a silane coupling agent. J Mater Sci Mater Med 2000;11:491497.

47. Simon CG, Khatri CA, Wight SA, Wang FW. Preliminary report on the biocompatibility of a moldable, resorbable, composite bone graft consisting of calcium phosphate cement and poly(lactide-co-glycolide) microspheres. J Orthop Res 2002;20: 473-482.

48. Xu HHK, Martin TA, Antonucci JM, Eichmiller FC. Ceramic whisker reinforcement of dental composite resins. J Dent Res 1999;78:706-712.

49. Kjuus H, Andersen A, Langard S. Incidence of cancer among workers producing calcium carbide. Br J Ind Med 1986;43:237242 . 